\title{
Front Matter: Volume 7227
}

, "Front Matter: Volume 7227," Proc. SPIE 7227, Complex Light and Optical Forces III, 722701 (19 February 2009); doi: 10.1117/12.823972

SPIE Event: SPIE OPTO: Integrated Optoelectronic Devices, 2009, San Jose, California, United States 


\section{PROCEEDINGS OF SPIE}

\section{Complex Light and Optical Forces III}

Enrique J. Galvez

David L. Andrews

Jesper Glückstad

Editors

28-29 January 2009

San Jose, California, United States

Sponsored and Published by

SPIE 
The papers included in this volume were part of the technical conference cited on the cover and title page. Papers were selected and subject to review by the editors and conference program committee. Some conference presentations may not be available for publication. The papers published in these proceedings reflect the work and thoughts of the authors and are published herein as submitted. The publisher is not responsible for the validity of the information or for any outcomes resulting from reliance thereon.

Please use the following format to cite material from this book:

Author(s), "Title of Paper," in Complex Light and Optical Forces III, edited by Enrique J. Galvez, David L. Andrews, Jesper Glückstad, Proceedings of SPIE Vol. 7227 (SPIE, Bellingham, WA, 2009) Article CID Number.

ISSN 0277-786X

ISBN 9780819474735

Published by

SPIE

P.O. Box 10, Bellingham, Washington 98227-0010 USA

Telephone +1 3606763290 (Pacific Time) · Fax +1 3606471445

SPIE.org

Copyright (C) 2009, Society of Photo-Optical Instrumentation Engineers

Copying of material in this book for internal or personal use, or for the internal or personal use of specific clients, beyond the fair use provisions granted by the U.S. Copyright Law is authorized by SPIE subject to payment of copying fees. The Transactional Reporting Service base fee for this volume is $\$ 18.00$ per article (or portion thereof), which should be paid directly to the Copyright Clearance Center (CCC), 222 Rosewood Drive, Danvers, MA 01923. Payment may also be made electronically through CCC Online at copyright.com. Other copying for republication, resale, advertising or promotion, or any form of systematic or multiple reproduction of any material in this book is prohibited except with permission in writing from the publisher. The CCC fee code is 0277-786X/09/\$18.00.

Printed in the United States of America.

Publication of record for individual papers is online in the SPIE Digital Library.

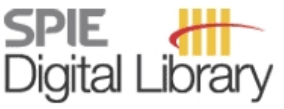

SPIEDigitalLibrary.org

Paper Numbering: Proceedings of SPIE follow an e-First publication model, with papers published first online and then in print and on CD-ROM. Papers are published as they are submitted and meet publication criteria. A unique, consistent, permanent citation identifier (CID) number is assigned to each article at the time of the first publication. Utilization of CIDs allows articles to be fully citable as soon they are published online, and connects the same identifier to all online, print, and electronic versions of the publication. SPIE uses a six-digit CID article numbering system in which:

- The first four digits correspond to the SPIE volume number.

- The last two digits indicate publication order within the volume using a Base 36 numbering system employing both numerals and letters. These two-number sets start with 00, 01, 02, 03, 04 , 05, 06, 07, 08, 09, OA, OB ... 0Z, followed by 10-1Z, 20-2Z, etc.

The CID number appears on each page of the manuscript. The complete citation is used on the first page, and an abbreviated version on subsequent pages. Numbers in the index correspond to the last two digits of the six-digit CID number. 


\title{
Contents
}

\author{
$\checkmark$ Conference Committee \\ vii Introduction
}

\section{SESSION 1 COMPLEX LIGHT GENERATION}

722704 Cylindrical vector beam generation from spun fiber [7227-03]

H. I. Sztul, The City College and Graduate School of CUNY (United States); D. A. Nolan, Corning, Inc. (United States); G. Milione, The City College and Graduate School of CUNY (United States); X. Chen, J. Koh, Corning, Inc. (United States); R. R. Alfano, The City College and Graduate School of CUNY (United States)

\section{SESSION 2 BIOLOGICAL APPLICATIONS OF OPTICAL TWEEZERS}

722706 Inhibition of yeast growth during long term exposure to laser light around $1064 \mathbf{n m}$ (Invited Paper) [7227-05]

T. Aabo, Copenhagen Univ. (Denmark); I. R. Perch-Nielsen, J. S. Dam, D. Z. Palima, Technical Univ. of Denmark (Denmark); H. Siegumfeldt, Copenhagen Univ. (Denmark); J. Glückstad, Technical Univ. of Denmark (Denmark); N. Arneborg, Copenhagen Univ. (Denmark)

\section{SESSION 3 BEAM MANIPULATION IN OPTICAL TWEEZERS}

722708 Angular spectrum tailoring in solid immersion microscopy [7227-07]

S. B. Ippolito, IBM Semiconductor Research and Development Ctr. (United States); P. Song, IBM T.J. Watson Research Ctr. (United States); D. L. Miles, J. D. Sylvestri, IBM Semiconductor Research and Development Ctr. (United States)

722709 High numerical aperture focusing of singular beams [7227-08]

A. Normatov, B. Spektor, J. Shamir, Technion-Israel Institute of Technology (Israel)

\section{SESSION 4 SINGULAR OPTICS AND OPTICAL VORTICES}

7227 OA Chain topological reactions in developing random light fields (Invited Paper) [7227-09]

V. Vasil'ev, V. Ponevchinsky, M. Soskin, Institute of Physics (Ukraine)

7227 OB Composite vortices of displaced Laguerre-Gauss beams [7227-10]

D. M. Kalb, E. J. Galvez, Colgate Univ. (United States) 


\section{SESSION 5 OPTICAL FORCES AND ANGULAR MOMENTUM}

7227 OD Vaterite twist: microrheology with AOM controlled optical tweezers [7227-12]

M. Funk, Technische Univ. München (Germany) and The Univ. of Queensland (Australia);

S. J. Parkin, T. A. Nieminen, N. R. Heckenberg, H. Rubinsztein-Dunlop, The Univ. of

Queensland (Australia)

7227 OE Optical forces arising from phase gradients [7227-13]

D. G. Grier, B. Sun, F. C. Cheong, Y. Roichman, New York Univ. (United States); S. H. Lee, Univ. of California, Berkeley (United States); Y. Roichman, Tel Aviv Univ. (Israel); J. Amato-Grill, New York Univ. (United States)

7227 OG Momentum of optical Airy beams [7227-15]

H. I. Sztul, R. R. Alfano, The City College and Graduate School of CUNY (United States)

$7227 \mathrm{OH} \quad$ Stability properties of a rotating astigmatic optical cavity [7227-16]

S. J. M. Habraken, G. Nienhuis, Leiden Univ. (Netherlands)

\section{SESSION 6 QUANTUM EFFECTS AND COMPLEX LIGHT}

7227 Ol Angular diffraction (Invited Paper) [7227-17]

S. Franke-Arnold, B. Jack, J. Leach, M. J. Padgett, Univ. of Glasgow (United Kingdom)

\section{POSTER SESSION}

$7227 \mathrm{OL} \quad$ Generation of vortex array laser beams with Dove prism embedded unbalanced Mach-Zehnder interferometer [7227-20]

S.-C. Chu, National Cheng-Kung Univ. (Taiwan)

Author Index 


\title{
Conference Committee
}

\author{
Symposium Chair
}

James G. Grote, Air Force Research Laboratory (United States)

Symposium Cochair

E. Fred Schubert, Rensselaer Polytechnic Institute (United States)

Program Track Chair

Zameer U. Hasan, Temple University (United States)

Conference Chair

Enrique J. Galvez, Colgate University (United States)

Conference Cochairs

David L. Andrews, University of East Anglia Norwich (United Kingdom)

Jesper Glückstad, Danmarks Tekniske Universitet (Denmark)

\section{Program Committee}

Nicholas P. Bigelow, University of Rochester (United States)

Shu-Chun Chu, National Cheng Kung University (Taiwan)

Kishan Dholakia, University of St. Andrews (United Kingdom)

Wolfgang A. Ertmer, Universität Hannover (Germany)

Jean-Marc R. Fournier, École Polytechnique Fédérale de Lausanne (Switzerland)

David G. Grier, New York University (United States)

Gerard Nienhuis, Universiteit Leiden (Netherlands)

Miles J. Padgett, University of Glasgow (United Kingdom)

Halina H. Rubinsztein-Dunlop, The University of Queensland (Australia)

Grover A. Swartzlander, Jr., College of Optical Sciences, The University of Arizona (United States)

Juan P. Torres, Institut de Ciències Fotòniques (Spain)

Ewan M. Wright, College of Optical Sciences, The University of Arizona (United States) 


\section{Session Chairs}

1 Complex Light Generation

Enrique J. Galvez, Colgate University (United States)

2 Biological Applications of Optical Tweezers

Jesper Glückstad, Danmarks Tekniske Universitet (Denmark)

3 Beam Manipulation in Optical Tweezers

Jesper Glückstad, Danmarks Tekniske Universitet (Denmark)

$4 \quad$ Singular Optics and Optical Vortices

Gerard Nienhuis, Universiteit Leiden (Netherlands)

5 Optical Forces and Angular Momentum

Grover A. Swartzlander, Jr., College of Optical Sciences, The University of Arizona (United States)

6 Quantum Effects and Complex Light

Halina H. Rubinsztein-Dunlop, The University of Queensland (Australia) 


\section{Introduction}

The intrinsic properties of light beams with structured wavefronts, and in particular, the generation of these beams and their use for manipulating objects at the micro- and nano-scale level is a topic of intense research today, as exhibited by the presentations at the second conference on Complex Light and Optical Forces III, and the corresponding articles contained in this volume. Together with complex light beams comes the presence of optical singularities, whose properties and applications are rich and under ongoing study.

The presentations at the conference touched on various forms of optical singularities: shear singularities, polarization singularities, and the ubiquitous optical vortices. Presentations reported on the generation of optical beams with singularities, the propagation and evolution of singularities in either in free space or in optical media, the diffraction of singular beams off optical structures, the generation of new types of singular beams, and the stability of modes in asymmetric rotating optical cavities.

The conference highlighted the strong mix of fundamentals and applications. It included the latest advances in the use of light to exert forces and torques on individual atoms or molecules and macroscopic objects via optical tweezers. Some talks focused on the fundamentals and methods of manipulating objects with the phase gradients in the optical field. Rapid advances in the field have yielded exquisite control over trapped micron sized objects opening them up as useful tools for biological applications. The presentations also included the effect of the trapping forces on the reproductive behavior of living cells.

The conference ended with a session on the increasing entry of singular beams into quantum mechanical systems and their use in fundamental tests of quantum mechanics and in applications in quantum information. The role of optical forces in quantum systems such as Bose-Einstein condensates and their interactions with singular beams was underscored.

In summary, Complex Light and Optical Forces III was successful in underscoring the recent advances in a growing field that promises new fundamental contributions to optics and important photonic applications.

Enrique J. Galvez David L. Andrews Jesper Glückstad 
Downloaded From: https://www.spiedigitallibrary.org/conference-proceedings-of-spie on 26 Apr 2023

Terms of Use: https://www.spiedigitallibrary.org/terms-of-use 